\title{
PESCADORAS ARTESANAIS DE MAGÉ (RJ): Um Estudo Etnogeográfico
}

\author{
Carla Ramôa Chaves ${ }^{i}$
}

\begin{abstract}
Resumo: a pesca é vista como uma atividade exclusivamente masculina. Mulheres participam das etapas do beneficiamento do pescado, mas não são reconhecidas como pescadoras, o que interfere na regulação profissional. Neste artigo analisamos as dificuldades que as pescadoras artesanais do município de Magé (RJ) têm no reconhecimento de suas identidades e os problemas, em comum, que elas enfrentam. Utilizamos os métodos member get member e observação participante, que possibilitaram a coleta de dados primários, através de entrevistas e observações. Os resultados apresentados levantam questionamentos acerca dos conceitos de comunidade e identidade, os quais foram discutidos em diálogos com Weber (2010) e Pollak (1995). Baseado nisso, concluímos que a comunidade dessas pescadoras se constitui a partir das práticas espaciais em comum, modos de vida e dificuldades enfrentadas. Além disso, apesar de se reconhecerem como pescadoras artesanais, suas identidades para os "outros" não são coesas o suficiente, para que haja o reconhecimento institucional e profissional.
\end{abstract}

Palavras-chave: pescadoras artesanais; etnogeografia; identidade; comunidade.

\section{CRAFT FISHERWOMEN FROM MAGÉ (RJ): AN ETHNOGEOGRAPHIC STUDY}

\begin{abstract}
The women, usually wives, participate in fishing and other stages of fish processing. In this article we analyze the difficulties that craft fisherwomen in Magé municipality have in recognizing their identities and the problems they face. We use the member get member and participant observation methods. This made it possible to collect primary data, through interviews and observations. The results presented raise questions about the concepts of community and identity. The results presented raise questions about the concepts of community and identity, which were discussed in dialogues with Weber (2010) and Pollak (1995). Based on this, we conclude that the community of these fisherwomen is constituted from the common space practices, ways of life and difficulties faced. In addition, despite recognizing themselves
\end{abstract}

\footnotetext{
' Doutora em Geografia, Universidade Federal do Rio de Janeiro, carla.ramoa.chaves@hotmail.com, https://orcid.org/0000-0002-4425-0277.
} 
as craft fisherwomen, their identities for "others" are not cohesive enough, so that there is institutional and professional recognition.

Keywords: craft fisherwomen; ethnogeography; identity; community.

\title{
PESCADORAS ARTESANALES DE MAGÉ (RJ): UN ESTUDIO ETNOGEOGRÁFICO
}

\begin{abstract}
Resumen: la pesca se considera una actividad exclusivamente masculina. Mujeres participan en las etapas del procesamiento del pescado, pero no son reconocidas como pescadoras, lo que dificulta la regulación profesional. En este artículo, analizamos las dificultades que tienen las pescadoras artesanales del municipio de Magé (RJ) para que se reconozcan sus identidades, y los problemas, en común, que enfrentan. Utilizamos los métodos member get member y observación participante, lo que permitió la recolección de datos primarios, mediante entrevistas y observaciones. Los resultados presentados generaron preguntas sobre los conceptos de comunidad e identidad, que fueron discutidos en diálogos con Weber (2010) y Pollak (1995). Con base en esto, concluimos que la comunidad de estas pescadoras se constituye a partir de las prácticas espaciales comunes, estilos de vida y dificultades que enfrentan. Además, a pesar de reconocerse a sí mismas como pescadoras artesanales, sus identidades para los "otros" no son lo suficientemente cohesivas, para que haya un reconocimiento institucional y profesional.
\end{abstract}

Palabras clave: pescadoras artesanales; etnogeografía; identidad; comunidad.

\section{Introdução}

A atividade pesqueira é vista como exclusivamente masculina. Em um núcleo familiar, enquanto os pescadores vão ao mar, as mulheres se dedicam às atividades domésticas (MANESCHY, 1995; MARTINS, 2008; GERBER, 2013). Dentre essas atividades domésticas estão enquadradas as etapas do beneficiamento da pesca que vão desde a captura do pescado (caranguejo, siri, camarão ou peixe) - e, dependendo do tipo do animal, passa pela descamação, descarnadura, filetagem e encordoamento - até as vendas. Uma questão que se apresenta é que a única parte reconhecida como pesca, de fato, é a captura do pescado. As demais etapas são consideradas "apoio à pesca artesanal".

Existe um decreto federal 8.424/2015 que contém a seguinte sentença: “A concessão do benefício não será extensível aos trabalhadores de apoio à pesca artesanal" (BRASIL, 
2015, Art. 1, § 69). O trecho deste parágrafo se refere ao pagamento do seguro defeso, aos pescadores, no período em que a pesca é proibida, para reprodução e desova das espécies. Porém, o decreto considera que somente aqueles que vão ao mar e ao mangue são pescadores artesanais, de fato, desconsiderando, completamente, as demais etapas do processo, trabalhadas por outras pessoas. Como a maioria dos "trabalhadores de apoio à pesca artesanal" são mulheres, este decreto dificulta o reconhecimento delas como pescadoras artesanais.

Para ter acesso aos benefícios sociais como trabalhador, os pescadores e pescadoras artesanais precisam, em primeiro lugar, fazer o cadastro no Registro Geral da Atividade Pesqueira (RGP), regulado pelo Ministério da Agricultura, Pecuária e Abastecimento (MAPA), do governo brasileiro. A partir deste registro, esses indivíduos passam a ter o direito de se inscrever como "segurado especial" no Instituto Nacional do Seguro Social (INSS), vinculado ao Ministério da Economia. Com o RGP, esses trabalhadores têm acesso aos benefícios trabalhistas, como o seguro defeso. Já com a inscrição no INSS, eles passam a ter acesso aos benefícios previdenciários, como auxílio-doença, auxíliomaternidade, aposentadoria, entre outros (SILVA, 2015).

Como as mulheres, muitas vezes, mesmo que participem de todo o processo da pesca, não conseguem o reconhecimento como pescadora artesanal, mas, sim, como "apoio à pesca", ficam de fora dos cadastros no RGP, no INSS, perdendo todos os benefícios trabalhistas e previdenciários, mesmo que trabalhem a vida inteira com essa atividade. O reconhecimento da identidade da pescadora artesanal é mais rápido quando esta vai, pessoalmente, ao mar ou ao mangue capturar o pescado. Porém, através dessa pesquisa e das informações adquiridas de pescadoras artesanais do município de Magé, no Rio de Janeiro, através de entrevistas, vimos que, mesmo indo diretamente à captura, as mulheres são desencorajadas a adquirir o RGP.

Na literatura, a maioria das autoras, que se dedicaram ao estudo de algum aspecto da atuação das mulheres na pesca, constataram uma forte divisão de trabalho baseada no gênero, já que muitas vezes a pesca é vista como atividade masculina (MANESCHY, 1995; MARTINS, 2008; GERBER, 2013). A forma como essa divisão de trabalho se instaura, 
principalmente nos núcleos familiares, produz uma "tripla" jornada de trabalho, em relação ao trabalho masculino (MANESCHY, 1995; DI CIOMMO, 2007; FASSARELA, 2008; SOARES, 2012).

A divisão de trabalho desigual e a "tripla" jornada de trabalho são resultados da invisibilidade feminina na pesca artesanal (FASSARELA, 2008; MANESCHY, 1993, 1995,1996; DI CIOMMO, 2007; SOARES, 2012; MARTINS, 2008; GERBER, 2013; FERREIRA, 2016), o que evidencia alguns problemas como: (a) se a participação da mulher na pesca é trabalho ou atividade doméstica, (b) se a baixa ou nula remuneração da mulher está relacionada com a pesca como atividade doméstica e (c) se a atuação da mulher na atividade pesqueira é desvalorizada, passando pelo constrangimento, muitas vezes, de ter sua identidade, como pescadora, questionada.

Sobre o primeiro problema, (a) se a participação da mulher na pesca é trabalho ou atividade doméstica, FASSARELA (2008) constatou que as próprias mulheres da comunidade de pescadores de Rio Grande (RS) confundem as atividades pesqueiras como tarefas domésticas. Do mesmo modo, MANESCHY (1996) afirma que, mesmo as mulheres tendo papel fundamental na "manutenção das famílias", as atividades desempenhadas por elas "não gozam do mesmo status das exercidas pelos homens, pois são concebidos como complementares" (MANESCHY, 1996: 156), referindo-se à pesca. A consequência dessa concepção é uma secundarização do trabalho feminino, o que culmina em uma ausência de remuneração e reconhecimento.

Em relação ao segundo problema, (b) a baixa ou nula remuneração da mulher nas etapas da atividade pesqueira, que não são a captura, leva algumas pescadoras a recorrerem a uma complementação na renda da família, acumulando outros trabalhos às atividades doméstico e pesqueira. Segundo MANESCHY (1995), os trabalhos extras ajudam no sustento da família, principalmente, se ocorre a diminuição na pesca. Nas comunidades estudadas por MANESCHY (1995), no Pará, “o trabalho remunerado da mulher passa a assumir caráter essencial no sustento das famílias" (MANESCHY, 1995: 147). 
Em nossa pesquisa, encontramos mulheres que trabalham em casa, com o marido na pesca e, também, buscam outros trabalhos remunerados - catadoras de papel, cuidadora de crianças, artesãs etc. Encontramos, também, o caso de uma pescadora, cujo relato está neste artigo, em que a sua pesca se tornou atividade remunerada, complementar à renda do marido, que é funcionário público. Mesmo esta mulher sendo pescadora artesanal, a colônia a desencorajou a cadastrar-se no RGP, perdendo todos os acessos aos benefícios concedidos a um trabalhador. O motivo é que seu marido já tinha um emprego fixo e garantido, como funcionário público, o que nos leva ao terceiro problema destacado: (c) a atuação da mulher na atividade pesqueira é desvalorizada, passando pelo constrangimento, muitas vezes, de ter sua identidade, como pescadora, questionada.

Diante da exposição até o momento, o objetivo deste artigo é apresentar alguns aspectos de um estudo sobre pescadoras artesanais de Magé, que enfrentam dificuldades relacionadas às suas existências e ao reconhecimento de suas identidades de si, para si e para os outros (POLLAK, 1995). A pesquisa foi iniciada a partir de uma denúncia feita por pescadoras artesanais que compareceram a uma audiência pública na Assembleia Legislativa do Rio de Janeiro (ALERJ) ${ }^{1}$, em 2015, as quais relataram dificuldades no recebimento do Seguro Defeso e no cadastramento no RGP.

Para isso, separamos alguns resultados da pesquisa da tese de doutorado "NOS MANGUEZAIS E NO “MAR” DE MAGÉ (RJ): um estudo sobre pescadoras artesanais e suas existências, resistências e identidade", defendida no Programa de Pós-Graduação em Geografia da Universidade Federal do Rio de Janeiro, em março de 2021. A partir destes resultados selecionados, organizamos este artigo em três partes.

A primeira parte tem o objetivo de expor a metodologia adotada, baseada na realização de um trabalho de campo inspirado na antropologia, no que Claval $(1999,2002)$ chama ora de geografias vernaculares (CLAVAL, 2002: 163), ora de etnogeografias (CLAVAL, 1999). Para isso dividimos esta parte em três subtítulos. O primeiro é sobre Trabalho de

${ }^{1}$ http://aleriln1.aleri.ri.gov.br/comtemp.nsf/0d034cff75b288de03256bb1005be7f8/9e86d7320dd9c76c8 3257ef800688d34?OpenDocument. 
campo: geografias vernaculares ou etnogeografia. Neste item, dialogamos com autores clássicos da antropologia como BERREMAN (1962), MALINOWSKI (1961), GLUCKMAN (1958), SEEGER (1980) e FOOTE-WHITE (1943) e com o geógrafo CLAVAL (1999, 2002, 2013).

A partir destas leituras, sobre seus trabalhos de campo, baseados em observação participante, controle de impressões e análise de situações sociais, traçamos estratégias de aproximação aos indivíduos, o que está exposto no segundo subtítulo Estratégia de aproximação, dificuldades, dúvidas e soluções, onde pedimos licença para escrever em primeira pessoa. Neste item, apresentamos algumas etapas do trabalho de campo etnogeográfico, cujas inspirações, semelhanças e diferenças, nas dificuldades e dúvidas que os pesquisadores experienciam, foram vistas nas pesquisas de GLUCKMAN (1958), COSTA (2013), SEEGER (1980), FOOTE-WHITE (1943) e MARTINS (2005).

No terceiro subtítulo, apresentamos a área de estudo Magé: espaço vivido das pescadoras artesanais e zona de sacrifício. Este espaço, diante de tantos códigos espaciais que lhe pode ser conferido, aqui neste artigo, o apresentamos como espaço vivido das pescadoras artesanais e, também, como parte de uma zona de sacrifício maior, que é o Recôncavo da Guanabara onde se localizam municípios da Baixada Fluminense, conforme concebido por LAMÊGO (1964), DIAS e outros (2013), RAULINO (2013), ALERJ (2016), OLIVEIRA, SÁNCHEZ (2018) e COELHO (2017).

A segunda parte deste artigo foi dividida em duas partes: Acúmulo de atividades paralelas à pesca e dificuldades no reconhecimento das identidades e Problemas enfrentados pelas pescadoras artesanais de Magé: os casos de Nícia, Mônica, Kelly e Ingrid. Em ambos os subtítulos, apresentamos alguns resultados obtidos através das informações adquiridas nas entrevistas com as pescadoras artesanais de Magé, realizadas durante o trabalho de campo. Estes resultados revelaram, dentre outras questões, o acúmulo de atividades, por estas mulheres, e, também, a dificuldade que elas têm no reconhecimento de suas identidades. No segundo subtítulo, ilustramos estas informações com os casos de quatro pescadoras artesanais. 
Na terceira parte, e última, apresentamos discussões com dois sociólogos WEBER (2010) e POLLAK (1995) sobre a necessidade de sanar três questões que surgiram a partir dos resultados apresentados neste artigo. A primeira questão foi discutida no primeiro subtítulo desta parte, o qual nomeamos como Oferta de dados secundários sobre pescadores artesanais. A baixa oferta destas informações secundárias revela a raridade de pesquisas sobre pescadores artesanais, principalmente, na Baía de Guanabara e seus municípios do entorno, e a dificuldade de implementar políticas públicas eficientes para este público, já que não existe uma contagem destes indivíduos, por exemplo. Esta problemática nos fez recorrer ao método member get member, que nos ajudou a encontrar parte desse público, que são as pescadoras.

A segunda questão foi discutida na parte intitulada Existe uma comunidade de pescadoras artesanais? Ou, existem pescadoras na comunidade de pescadores artesanais? Esta dúvida surgiu por não termos encontrado com facilidade as pescadoras, diferente do que vimos em estudos sobre pescadoras artesanais de outras localidades. Diante disso, nos apoiamos em WEBER (2010) que apresenta várias possibilidades de compreensão sobre a constituição de uma comunidade, o que nos ajudou nessa questão.

A terceira questão, ainda referente à terceira e última parte deste artigo, discute a Identidade das pescadoras artesanais de Magé, de si, para si e para os "outros". Esta questão foi levantada diante da nossa percepção de que, apesar das pescadoras artesanais de Magé trabalharem com pesca, seja no mar, no mangue ou apenas nas etapas do beneficiamento, elas têm dificuldades em ter a sua identidade, de si e para si, reconhecida pelos "outros". Nesse caso, os "outros" são as instituições de regulamentação da atividade pesqueira, que em nossa pesquisa é a colônia de pescadores local.

Trabalho de Campo: "geografias vernaculares" ou etnogeografia 
Nesta pesquisa, privilegiamos um trabalho de campo mais íntimo, aos moldes da antropologia e da etnogeografia, para que fosse possível atingir a "região interior" (BERREMAN, 1962) do grupo de pescadoras artesanais investigadas e conseguirmos responder aos questionamentos que deram início ao estudo em pauta. Um dos questionamentos, o qual trataremos neste artigo, se refere aos obstáculos que as pescadoras artesanais de Magé enfrentam para a sua sobrevivência, enquanto trabalhadora do mar e do mangue, e ao respeito às suas identidades, pelas instituições que regulamentam a atividade pesqueira.

Nos estudos geográficos, os trabalhos de campo não são descritos com seus dramas e dificuldades encontradas, tal qual ocorrem nas pesquisas antropológicas. O trabalho de campo revela surpresas, fazendo-nos perceber que o problema não é o preconcebido pelo pesquisador ou pesquisadora, que o espaço estudado não é o mesmo apresentado na literatura e os grupos sociais vivem e se organizam de outra forma, a partir do olhar do investigador. Através do campo, as estratégias de aproximação e observação modificam-se e adaptam-se à realidade que se desvela para o pesquisador, diferente do apresentado pela literatura.

A partir dessas premissas e compreensão da importância do trabalho de campo, nos inspiramos e dialogamos com antropólogos clássicos e respeitados como MALINOWSKI (1961), GLUCKMAN (1958), SEEGER (1980) e FOOTE-WHITE (1943). Em vários momentos do trabalho de campo, nos reconhecemos em situações enfrentadas pelos antropólogos estudados, o que nos auxiliou no prosseguimento e no melhor aproveitamento das informações primárias adquiridas na pesquisa. No campo da geografia, utilizamos autores que valorizam os métodos qualitativos, aplicados neste estudo, como por exemplo CLAVAL $(1999,2002,2013)$ que possui uma compreensão do trabalho de campo que vai além do observar, descrever e mapear, mas, também, dar voz aos sujeitos e "garantir a autenticidade das observações coletadas e proporcionar a descoberta de realidades que escapam às outras estratégias de investigação" (CLAVAL, 2013, parágrafo $1)$. 
CLAVAL (1999) cita "geógrafos que estudam há muito tempo a orientação [espacial] praticada por diferentes povos e as expressões verbais ou gráficas feitas por eles", no que ele chama de "campo da curiosidade etnogeográfica" (CLAVAL, 1999: 69). Estes estudos também foram inspirados por etnografias clássicas, como a do Levi-Strauss que analisou a "topografia da aldeia Bororo" (CLAVAL, 1999: 69). Os [etno]geógrafos citados por CLAVAL (1999) são Jean Gallais², Jöel Bonnemaison ${ }^{3}$, Jean Delvert ${ }^{4}$ e Augustin Berque $^{5}$, cujas etnogeografias, diferente das etnografias antropológicas, levam em consideração e valorizam, em primeiro plano, a dimensão espacial, como condição fundamental para a reprodução social do grupo estudado. Portanto, as etnogeografias se aproximam do que Claval chama de "geografias vernaculares de cada um" (CLAVAL, 2002: 163), que valorizam o estudo em uma escala particular, considerando o espaço como produto da relação com a sociedade que o habita.

\section{Estratégia de aproximação, dificuldades, dúvidas e soluções}

O trabalho de campo foi realizado no período entre os dias 20 e 30 de julho de 2019, quando me hospedei na casa de uma das pescadoras artesanais residentes em Magé, município do Estado do Rio de Janeiro. Nesse momento, peço licença para relatar essa experiência em primeira pessoa. Na casa dessa pescadora funciona a Associação de Moradores e Pescadores de São Francisco de Croará (AMOPE), localizada no distrito de Guia de Pacobaíba. Antes da hospedagem, compareci a alguns eventos organizados e apoiados pela associação, como ouvinte, como primeira estratégia de aproximação com as pescadoras artesanais da região.

\footnotetext{
${ }^{2}$ GALLAIS, Jean. Le Delta intérieur du Niger: étude de géographie régionale, Volumes 1-2. 1967. 625p.

${ }^{3}$ BONNEMAISON, Joel. Tanna: les hommes lieux. Editions de I'ORSTOM, 1987. 680p.

${ }^{4}$ DELVERT, Jean. Géographie de l'Asie du Sud-Est. Universitaires de France, 1974.

${ }^{5}$ BERQUE, A. Vivre l'Espace au Japon. Presses universitaires de France (réédition numérique FeniXX), 1982. $224 \mathrm{p}$. BERQUE, A. Le Sauvage et l'Artifice: les Japonais devant la nature. Gallimard, 1986. 314p. BERQUE, A. Du geste à la cité: formes urbaines et lien social au Japon, Paris, Gallimard, 1993.
} 
Comparecer em eventos é uma estratégia de antropólogos, como GLUCKMAN (1958: 229), com o intuito de observar "situações sociais" para, futuramente, analisá-las e sistematizá-las. No último evento comparecido, antes do campo em si, levei, estrategicamente, meu marido, baseada em relatos de etnografias, como o da antropóloga COSTA (2013), que observou que os habitantes de Itaquera, Bahía, só ofereceram hospedagem a ela após a chegada de seu marido ao campo (COSTA, 2013: 17):

Em sociedades onde a divisão de tarefas por gênero é fortemente marcada, uma mulher desacompanhada enfrenta uma série de dificuldades para ser aceita pelo grupo: seu lugar é em casa, e não andando sozinha, solta pelo mundo. (COSTA, 2013: 17)

De fato, com a presença de meu marido, a conversa com o casal de pescadores, donos da casa e presidentes da AMOPE, fluiu melhor e obtive convite para hospedar-me na associação. Com o intuito de me aproximar mais e conseguir reunir outras pescadoras, em um único evento, me ofereci para ensinar um artefato em uma oficina de artesanato, que fez sucesso na família. No entanto as pescadoras da comunidade não compareceram. Mesmo assim, esse evento foi útil, por poder contar com a ajuda dos donos da casa em uma maior imersão no campo, conforme o antropólogo SEEGER (1980) que só foi bem aceito dentre os índios Suyá, residentes do Parque Nacional do Xingu, após realizar uma apresentação musical ao grupo, de uma forma inusitada (SEEGER, 1980: 29).

Durante os primeiros dias de trabalho de campo, iniciei um survey, método usado por antropólogos, para reunir a amostragem, fazer um reconhecimento do terreno e sondar as pescadoras que viriam a ser as interlocutoras do meu estudo. Neste primeiro momento, fui acompanhada pela pescadora e vice-presidente da AMOPE, a qual se tornou minha principal colaboradora, como Doc, colaborador de pesquisa do antropólogo FOOTE-WHITE (1943) e, também, integrante do grupo social, foco de sua 
pesquisa (FOOTE-WHITE, 1943: 78-80). O survey começou pelas praias, durante dois dias, quando notei que não havia pescadoras em seus "esperados" ambientes de trabalho.

Imaginei, conforme a literatura, que encontraria uma comunidade pesqueira, bem estruturada, participativa nas reuniões de associações e eventos, homens e mulheres se encontrando na praia para pescar, pescadoras se encontrando em troca de saberes, enquanto estariam descamando peixes ou descarnando siri (MARTINS, 2005). Diante desta primeira dificuldade em encontrar a minha amostragem, cheguei a duvidar se haveria uma comunidade com pescadoras artesanais, em Magé.

Uma das soluções para encontrá-las foi realizar uma rede de indicações, através do método Member Get Member ou Bola de Neve, estratégia muito utilizada pelo Marketing (WEISS, $1994^{6}$ apud VEIGA; GONDIM, 2001: 6). A primeira pescadora entrevistada foi indicada por um indivíduo conhecido da vice-presidente da AMOPE, que encontramos durante o survey. Ao final desta primeira entrevista, pedi que ela me indicasse outra pescadora, que me indicou outra e assim por diante. Desse modo não as encontrei agrupadas, mas confinadas em suas atividades domésticas, acumuladas com a pesca, em uma tripla jornada de trabalho; sobrecarga evidente, comum ao trabalho feminino (MANESCHY, 1995: 148; DI CIOMMO, 2007: 158; FASSARELA, 2008: 188; SOARES, 2012: 73).

Foi a partir desse processo de indicações que conheci e entrevistei Nícia, Mônica, Kelly e Ingrid, cujos relatos serão apresentados parcialmente, mais adiante, como parte das informações adquiridas no desenvolvimento da pesquisa.

A partir desse método, durante dez dias, foram entrevistadas 19 mulheres pescadoras de siri, caranguejos, camarões e peixes variados. Inicialmente, o plano era realizar uma pesquisa baseada na observação participante, em reuniões, rodas de conversa e acompanhando um dia de trabalho, mas estes cenários não aconteceram, de modo que

\footnotetext{
${ }^{6}$ WEISS, Robert S. (1994) Learning from stranger: the art and method of qualitative interview studies. New York, The Free Press. Disponível no Google Books, apenas algumas partes.
} 
a estratégia precisou ser outra. As mulheres estavam sempre ocupadas, ou com atividades domésticas ou com a pesca, não sendo fácil conseguir uma audiência. Além dessas atividades, algumas complementavam com trabalhos extras, remunerados, 0 que as deixam com menos tempo para incluírem outros itens em suas agendas, como as entrevistas.

HOEFLE (2018), ao estudar pescadores do município de Mangaratiba, no Rio de Janeiro, chamou esse acúmulo de atividades de "oportunidades multifuncionais", que introduz "atividades justapostas" (HOEFLE, 2018: 99), o que torna os habitantes, de sua área de estudo, muito atarefados e ocupados. Segundo o autor, a multifuncionalidade é comum em áreas que são transformadas "de uma zona rural à periferia da região metropolitana" (HOEFLE, 2018: 104), como é o caso de Mangaratiba e, também, de Magé.

Desse modo, com o intuito de otimizar a pesquisa, parti para entrevistas com perguntas mais objetivas, mas com espaço para novos questionamentos. As entrevistas foram feitas de forma flexível, conforme orientação do geógrafo CLAVAL (2013), defensor da etnogeografia, que afirma que as entrevistas podem ser "não-diretivas" e o entrevistador precisa ser generoso na escuta da fala de seu interlocutor, permitindo que sejam levantados "aspectos relativamente novos - e diferentes daqueles que esperava - da realidade que analisa" (CLAVAL, 2013, parágrafo 112).

As entrevistas ofereceram relatos relevantes para a pesquisa, cujas conversas foram gravadas e, em seguida, organizadas em uma tabela, com pontos em comum em suas falas, o que permitiu contabilizar a frequência com que certos fatos ocorriam nesse universo de pescadoras. Além da contabilização das ocorrências em comum, cada pescadora tinha sua própria realidade e história particular. Dentre todas as ocorrências averiguadas na pesquisa, apenas duas serão expostas neste artigo: (a) o acúmulo de atividades paralelas, sobre as quais fiz uma lista das que foram citadas pelas entrevistadas e (b) a falha no reconhecimento das pescadoras pelas instituições reguladoras da atividade pesqueira, representadas aqui pela colônia de pescadores local. Sobre esta falha no reconhecimento, contabilizei as pescadoras que possuem o 
RGP e as que não possuem e, também, a quais órgãos recorreram para adquirir o registro de atividade pesqueira.

Apesar de ser possível reunir as pescadoras em uma mesma ocorrência em comum, os motivos que as levaram a tal fim foram esclarecidos pelos relatos. As quatro pescadoras, supracitadas, cujos relatos serão expostos mais adiante, apresentaram explicações diferentes para o não reconhecimento de suas identidades pela colônia e a não conquista de seus direitos trabalhistas e previdenciários, como consequência do não cadastramento no RGP e/ou a perda dele.

\section{Magé: espaço vivido das pescadoras artesanais e zona de sacrifício}

A área de estudo localiza-se no município de Magé, no Estado do Rio de Janeiro, e envolve trechos dos distritos de Guia de Pacobaíba, Suruí e Magé. Essa área foi delineada pelo método Member Get Member, que circunscreveu o espaço de acordo com as indicações e visitações às pescadoras em suas casas, para as entrevistas. Os limites dessa área não coincidem com a divisão política desses distritos, mas estão relacionados às localizações das habitações e dos ambientes de trabalho: as praias, os rios e os manguezais (Mapa 1). Mesmo que não tenhamos encontrado estas mulheres nesses ambientes de trabalho, todos foram relatados por elas durante as entrevistas.

$\mathrm{Na}$ área de abrangência da pesquisa, observamos e analisamos o espaço vivido das pescadoras artesanais e nos certificamos, através de marcas na paisagem (BERQUE, 1984), das presenças de agentes externos, como a indústria do petróleo, por exemplo (foto 1). Avaliamos que a presença desses agentes produz uma zona de sacrifício, no espaço estudado, o qual faz parte de um espaço maior, igualmente sacrificado pela atividade petrolífera, que engloba o Recôncavo da Baía de Guanabara, onde se encontram municípios da Baixada Fluminense, dentre eles Magé (LAMÊGO, 1964: 277; DIAS e outros, 2013: 172; RAULINO, 2013: 186; ALERJ, 2016: 179[245]; OLIVEIRA, SÁNCHEZ, 2018: 160; COELHO, 2017: 58-59). 
Revista Continentes (UFRRJ), ano 10, n. 18, 2021 


\section{Mapa 1 - Área de abrangência da pesquisa}

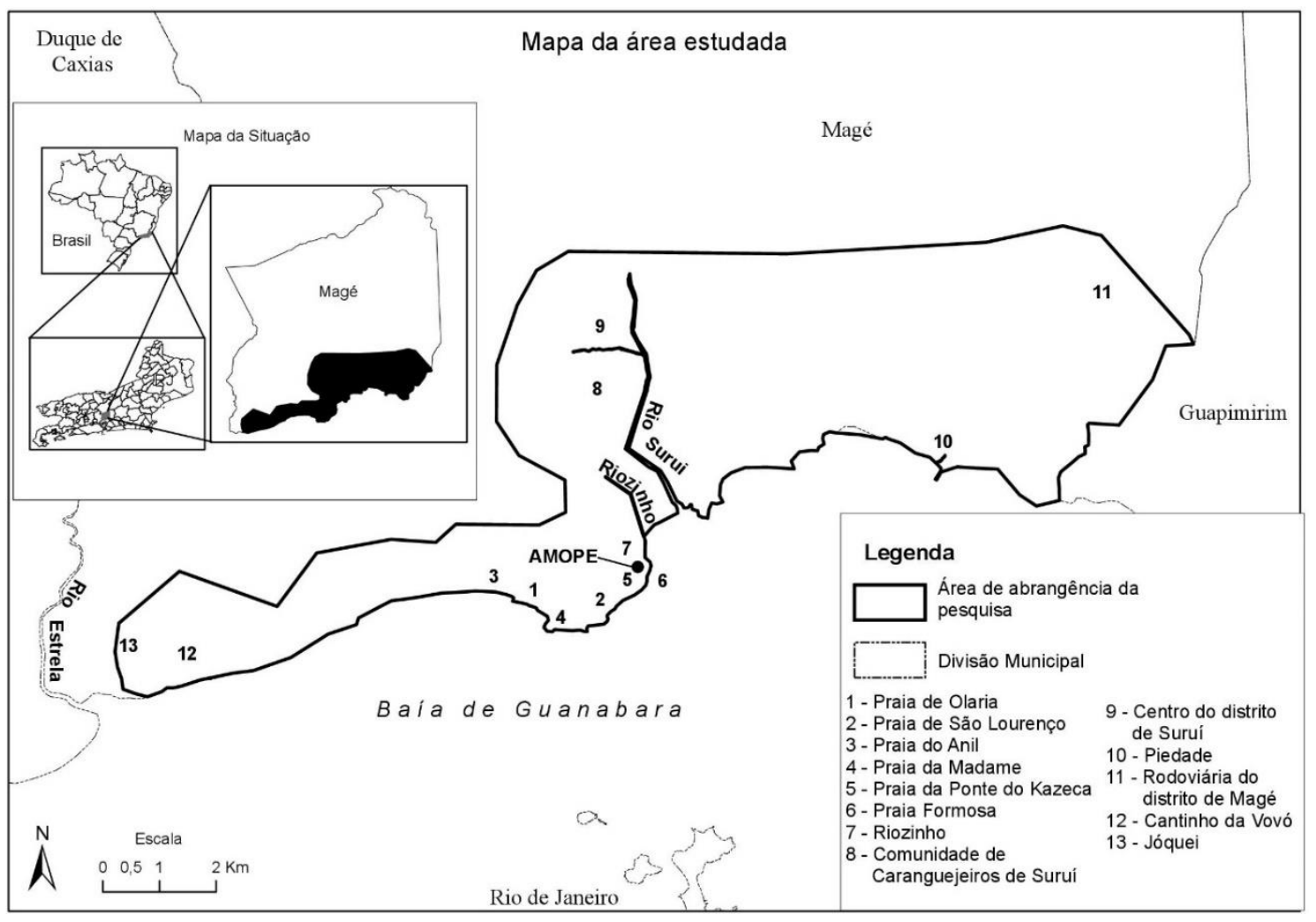

(CHAVES, 2021: 77).

Foto 1 - Placa sinalizando a presença de gasoduto enterrado (Cantinho da Vovó)

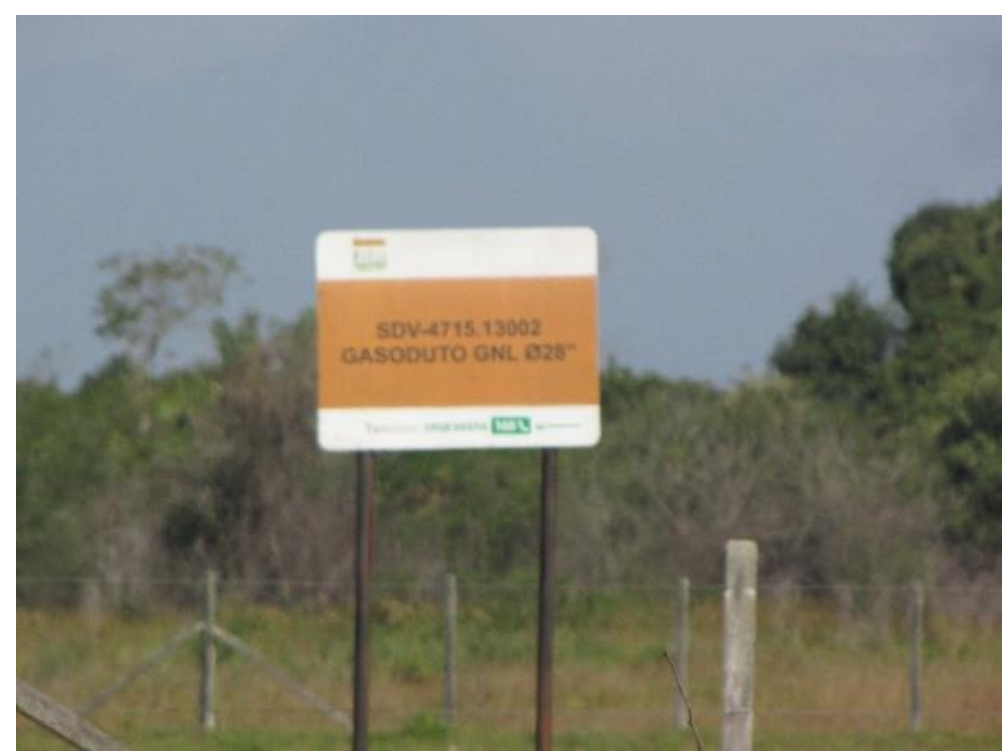

Fonte: CHAVES, 2021: 147.

Foto de 30/07/2019 
Além da indústria do petróleo, outros agentes externos atuam na área estudada, provocando resultados sobre o espaço e sobre as pescadoras que ali vivem. A presença da indústria garante a modernização da Região Metropolitana do Rio de Janeiro e o fornecimento energético nacional, mas interfere brutalmente na pesca local, apesar de não ter acabado com ela. Já a presença de organizações não-governamentais (ONG) e órgãos ambientais - através das unidades de conservação (UC) presentes - por outro lado, representam as ajudas aos pescadores e pescadoras artesanais, nas suas sobrevivências e subsistências. Auxílios que, por sua vez, também promovem o

"Para garantir o seu sustento e o da família, como

trabalhadoras do mangue e do mar, as pescadoras de Magé enfrentam questões relacionadas à pesca e ao acúmulo de atividades paralelas, que as auxiliam na economia doméstica, assim como também relacionadas ao reconhecimento de sua identidade pelos órgãos reguladores da atividade pesqueira (ministérios, secretarias e colônias de pescadores)". afastamento dos pescadores, e pescadoras, à atividade pesqueira, interferindo, nesse ponto, nas suas identidades.

Os agentes que auxiliam - ONGs e UCs - não são os únicos que interferem na identidade dos pescadores artesanais. A presença da colônia de pescadores local promove uma espécie de descontinuidade nas identidades, principalmente nas das pescadoras. Dos agentes citados, consideraremos, neste artigo, a colônia de pescadores, devido à relação direta com os dados e resultados selecionados, para serem contemplados nesta exposição.

$\mathrm{Na}$ área de estudo, a pesca é gerida pela colônia Z-9, a qual surgiu em todos os relatos dessa pesquisa. Para registrar-se no RGP, $42 \%$ das pescadoras entrevistadas procuram a colônia, embora não seja a única alternativa. Caso queiram, pescadores podem procurar diretamente o ministério da pesca (MAPA) ou a Secretaria de Aquicultura e Pesca (SAP), para fazerem o registro. A colônia de pescadores Z-9, como veremos nos relatos, tem um papel crucial na insegurança identitária das pescadoras de Magé, pois, em alguns casos, ao invés de 
promover o fortalecimento da atividade, com incentivos e medidas, ao contrário, desencorajou essas mulheres a regularizarem sua situação como profissional de pesca.

\section{Acúmulo de atividades paralelas à pesca e dificuldades no reconhecimento das identidades}

Como citado, entrevistamos 19 pescadoras artesanais indicadas através do member-getmember. Utilizamos este método pela dificuldade de encontrar, facilmente, as pescadoras nos locais de trabalho esperados, como as encontraram COLE (1991), em sua pesquisa com pescadoras da Vila Chã, um povoado na costa Norte de Portugal, MARTINS (2005), que acompanhou sirizeiras de São Gonçalo, que trabalhavam em "rodas de siri", e GERBER (2013), que as encontrou trabalhando nas praias do litoral de Santa Catarina.

Diante da dificuldade de encontrar as pescadoras e da necessidade de recorrer às indicações, uma das dúvidas que permearam esta pesquisa foi sobre a existência, de fato, de uma comunidade de pescadoras e pescadores, na região. A partir das entrevistas, os primeiros resultados da pesquisa se revelaram através das seguintes sentenças: a pesca não vale mais a pena e a vida das pescadoras é muito ocupada, devido ao acúmulo de atividades (tarefas domésticas, trabalhos temporários remunerados, etapas do beneficiamento da pesca, incluindo a venda do pescado), no que HOEFLE (2018) chama de "modos de vida multifuncionais" (HOEFLE, 2018: 104).

Para garantir o seu sustento e o da família, como trabalhadoras do mangue e do mar, as pescadoras de Magé enfrentam questões relacionadas à pesca e ao acúmulo de atividades paralelas, que as auxiliam na economia doméstica, assim como também relacionadas ao reconhecimento de sua identidade pelos órgãos reguladores da atividade pesqueira (ministérios, secretarias e colônias de pescadores).

Em relação à pesca e ao acúmulo de atividades paralelas, 63\% das mulheres entrevistadas vivem somente de pesca e $16 \%$ complementam a renda familiar com 
outras atividades remuneradas, como cuidadoras de crianças, empregadas domésticas, catadoras de resíduos recicláveis, artesãs e donas de pequenos quiosques na praia. As demais pescadoras, $21 \%$, não estão mais na atividade pesqueira. Dentre os motivos estão a busca por outras atividades mais rentáveis e seguras, do ponto de vista delas vendas no varejo e emprego doméstico - e a perda do RGP, que é o caso da Ingrid, que será apresentada mais adiante.

Já em relação ao reconhecimento da identidade dessas pescadoras pelos órgãos de pesca, 47\% possuem o RGP e 37\% não possuem esse registro. Em 2015, o RGP foi interrompido pelo MAPA, com a finalidade de atualizar os cadastros (MAPA, 2019: 13). As pescadoras que deram entrada no RGP a partir desse ano, $16 \%$, utilizam um protocolo como identificação de pescadora, o que garante, temporariamente, o acesso ao pagamento do seguro defeso ${ }^{7}$.

Problemas enfrentados pelas pescadoras artesanais de Magé: os casos de Nícia, Mônica, Kelly e Ingrid ${ }^{8}$

Outros resultados dessa pesquisa se apresentaram na forma de relatos dados em entrevistas informais com as pescadoras artesanais, durante visitas em suas próprias casas. Nessas conversas, foram relatados os principais problemas enfrentados por elas para terem suas sobrevivências garantidas como trabalhadoras do mangue e do mar. A partir das respostas, muitas vezes parecidas, conseguimos contabilizar em porcentagens, mas o mais interessante é a qualidade do que foi dito e não o quantitativo. É o caso dos relatos de Nícia, Mônica e Kelly, que serão parcialmente expostos a seguir.

7 http://www.cppnacional.org.br/noticia/vit\%C3\%B3ria-na-justi\%C3\%A7a-permite-aos-pescadores-epescadoras-artesanais-acessarem-o-seguro-defeso ${ }^{8}$ Nomes fictícios. 
Essas três pescadoras possuem entre 30 e 40 anos de trabalho somente na pesca e, apesar do tempo, não tiveram oportunidade de cadastrar-se no RGP. Sem este cadastro, as pescadoras não têm direito aos benefícios trabalhistas (seguro defeso) nem previdenciários (auxílio-doença e aposentadoria, por exemplo). O que estas três pescadoras têm em comum, além de não terem o RGP, é o desencorajamento, relatado por elas, por parte da colônia de pescadores local. Nícia relatou o seguinte:

Na colônia, eu fui uma vez só. Mas quando chegou lá, eles falaram... o rapaz que resolvia isso não estava mais lá. Eu não sei porque os outros, acho que tinham cisma com a gente. Aí peguei assim, ah, os outros só ficam enrolando a gente. Aí nós pegamos, fomos e paramos com isso... E aqueles que não é!! Tem mulher que nunca entrou no mangue e tem carteirinha e recebe o defeso. É isso o que mais invoca a gente. Aquelas mulher que fica na porta do botequim, bebendo, com uma unha grandona e recebe defeso. Agora, aqueles que é pescador mesmo, vive disso e não tem. A gente não recebe. $E$ como depois eles vão lá nas feira, querer proibir da gente vender uma coisa que a gente traz comida pra dentro de casa, pra gente comer? (Nícia, entrevista do dia 30/07/2019)

Mônica de 52 anos é sirizeira e não irá se aposentar, pois, apesar de ter 37 anos de trabalho como pescadora, não possui RGP, que é o ponto de partida para que os pescadores e pescadoras adquiram seus direitos. Em seu relato ela diz:

Fui lá em Mauá [colônia Z-9] pra fazer e o rapaz disse que não valia a pena, essa coisa toda, aí eu não fui pra frente, não. [Não insistiu] porque eu acho assim: quando a pessoa vai lá e a pessoa dá uma palavra assim ó...'tenta, não desiste não'! Ele já deu uma palavra bem... pra desanimar mesmo ... aí eu falei assim 'eu não vou insistir muito'. Se for da vontade de Deus vai acontecer, se não for... (Mônica, entrevista do dia 28/07/2019) 
O caso de Kelly é emblemático, pois seu marido é funcionário público, mas ela sempre foi pescadora e complementa a renda da família com a atividade. Ela foi desencorajada pela colônia de pescadores a cadastrar-se no RGP por "não precisar":

Eu tentei tirar, logo assim que eu estava vivendo da pesca, mas aí, como era parente, que estava lá na colônia, aí olhou para a minha cara e disse que eu não precisava. Eu não fiz questão, vim embora. Porque meu marido já estava empregado. Só que meu marido trabalhava e eu ficava pescando, mais uma renda. Aí ele achava que, como era funcionário público, meu marido, eu não precisava de renda. De mais uma renda. Eu estava ajudando dentro de casa. Aí ele [o funcionário da colônia] não fez. [Isso foi há quase 20 anos atrás, as meninas eram pequenas]. Porque o meu marido, o salário dele, só dava pra gente pagar as contas e eu botava o camarão dentro de casa, pra poder sobrar para outras coisas. Aí eu desisti. (Mônica, entrevista do dia 28/07/2019)

O desencorajamento por parte da colônia, produz um desmoronamento nas identidades dessas pescadoras, construídas por dois vetores: de si e para si, pela autoidentificação, e para o "outro", através do reconhecimento por parte dos órgãos que regulam a pesca, como a colônia, nesses casos relatados. As falas das pescadoras citadas demonstram que, apesar das suas identidades individuais, de si e para si, serem coesas, não são o suficiente para serem reconhecidas e respeitadas pela colônia, o que corresponde à identidade para o "outro", conforme POLLAK (1995).

O primeiro passo para o reconhecimento das pescadoras e pescadores é o registro no RGP. A colônia não é a única instituição competente para fazer este cadastro, pois os pescadores e pescadoras podem recorrer diretamente à SAP, vinculada ao MAPA, e às associações de pescadores existentes na região. Apesar disso, 42\% das entrevistadas procuraram a colônia Z-9 para dar entrada no RGP (gráfico 1).

Munidos do RGP, os pescadores e pescadoras passam a ter direitos aos benefícios trabalhistas e previdenciários. No entanto, o RGP conflita com a Carteira de Trabalho e Previdência Social (CTPS), o que significa que, caso o pescador, ou pescadora, queira 
complementar a renda como trabalhador assalariado, através da Consolidação das Leis Trabalhistas (CLT), ele ou ela precisará descadastrar-se do RGP. É o caso de Ingrid ${ }^{9}$ que, devido a essas escolhas, perdeu os benefícios previdenciários e trabalhistas, tanto pelo RGP quanto pelo CTPS.

Gráfico 1: Porcentagem das pescadoras entrevistadas em relação às instituições que procuraram para se registrarem no RGP. Informações adquiridas nas entrevistas

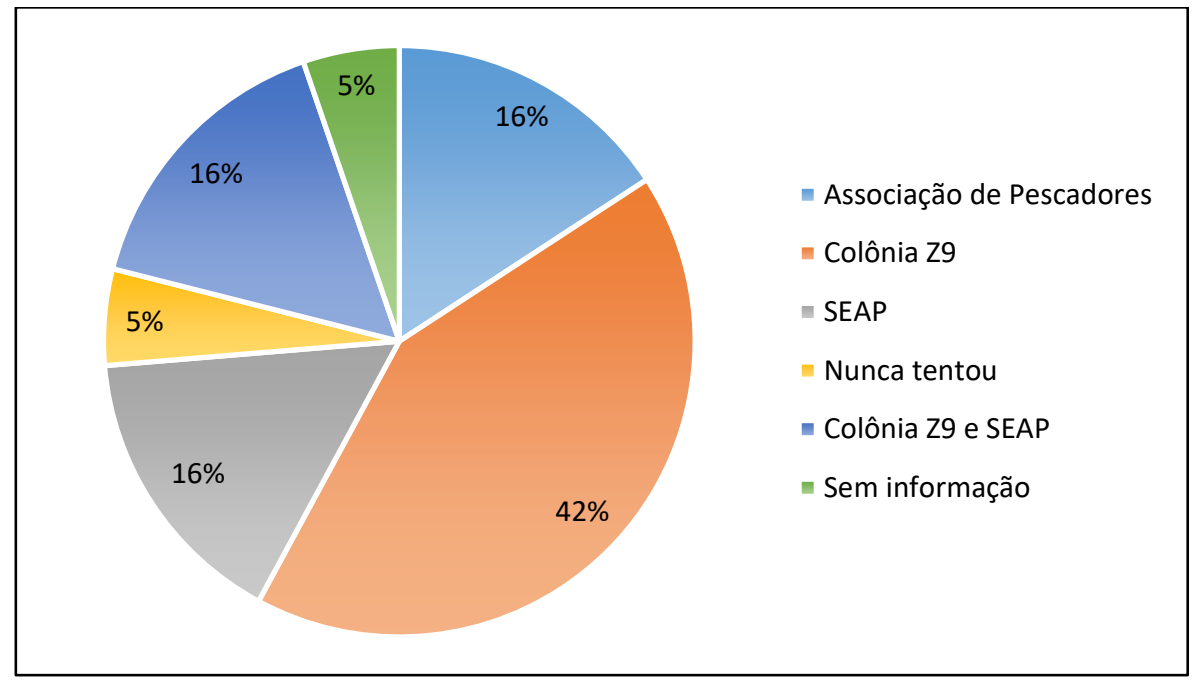

Fonte: CHAVES, 2021: 241.

*SEAP: Secretaria Especial de Aquicultura e Pesca (atualmente SAP)

Ingrid se autoidentifica pescadora, tinha RGP, mas perdeu seus direitos como tal, por ter aceitado uma curta temporada de trabalho ofertada por uma ONG, para participar do reflorestamento de manguezais do município de Magé, após um acidente com derramamento de óleo na Baía de Guanabara, em janeiro de 2000 (SEVÁ, 2013: 105). Ingrid pesca desde os 17 anos e registrou-se no RGP em 2005, tendo apenas 5 anos de contribuição ao INSS, como segurada especial ${ }^{10}$. Quando aceitou o trabalho na ONG,

\footnotetext{
${ }^{9}$ Nome fictício.

${ }^{10}$ Condição ofertada por direito ao pescador e pescadora artesanal.
} 
passou a ter a CTPS assinada, o que a fez perder o RGP e, por sua vez, a condição de segurada especial (SILVA, 2015: 63).

\begin{abstract}
A gente era pela Colônia Z-9, aí, chegou uma firma, a Petrobras contratou uma firma [áudio falho], mandou contratar 120 pescadores e, nisso, eu fui chamada. Fui contratada pela carteira [CTPS] e, nisso, cortaram minha carteira [de pescadora] (Ingrid, pescadora artesanal, em entrevista concedida no dia 30/07/2019).
\end{abstract}

Quando o projeto de reflorestamento findou, Ingrid tentou retornar à pesca e ao RGP, mas não conseguiu, pois ficou gravemente doente, nesse ínterim, e não conseguiu restaurar sua identidade institucional, como pescadora. O resultado é que, por estar doente, a pescadora teria direito ao auxílio-doença pelo INSS, tanto como RGP, quanto $\mathrm{CLT}$, mas a doença a acometeu antes da resolução do seu problema. Desse modo, apesar de ter cerca de 35 anos de trabalho na pesca, esta troca de RGP para CLT fez com que a entrevistada ficasse em uma espécie de "limbo", não pertencendo a nenhuma das categorias do INSS que lhe concederiam os benefícios de auxílio-doença ou aposentadoria por invalidez.

A apresentação dos resultados e relatos, contemplados neste artigo, necessitam de algumas discussões sobre questões que foram evidenciadas durante a coleta de dados. Uma das primeiras dessas questões é a baixa oferta de dados secundários referentes a pescadores artesanais. Não se sabe, ao certo, quantos pescadores existem no Brasil, nem nas regiões, e, por sua vez, não existem dados estatísticos relacionados, exclusivamente às pescadoras artesanais ${ }^{11}$.

A segunda discussão que queremos desenvolver, refere-se ao questionamento sobre a existência de comunidade de pesca, com pescadoras artesanais, em Magé. A dificuldade de encontrá-las em seus ambientes de trabalho "esperados" revelou esta problemática, indo contra grande parte da literatura estudada sobre comunidades pesqueiras. A

\footnotetext{
${ }^{11}$ A não ser que consideremos, somente, os pescadores artesanais que recebem o seguro defeso, logo possuem RGP. Estes dados estão disponíveis no portal de transparência do governo federal, a partir de 2013, apenas: http://www.portaltransparencia.gov.br/beneficios/consulta? ordenarPor $=$ mesAno\&direcao $=$ desc.
} 
terceira e última discussão que faremos, se refere às identidades das pescadoras, que são desencorajadas por uma das instituições representativas da pesca local, que é a colônia de pescadores. 


\section{Oferta de dados secundários sobre pescadores e pescadoras artesanais}

A oferta de dados secundários, estatísticos e numéricos, disponíveis, sobre pescadores artesanais, talvez não seja suficiente para realizarmos um estudo com base nestas informações. Em relação à Baía de Guanabara (BG), no Rio de Janeiro, essa regra não muda. Alguns autores, estudiosos sobre os pescadores artesanais dos municípios do entorno da BG, se esforçaram para organizar estas informações em suas pesquisas. 0 censo demográfico, do Instituto Brasileiro de Geografia Estatística (IBGE), não leva em consideração a quantidade de pescadores artesanais existentes nos setores censitários, mas, sim, informações sobre produção pesqueira, enquadrando pescadores junto com agricultores. Portanto, não existe um censo que reúna informações de pescadores artesanais da Baía de Guanabara (CHAVES, 2011: 89) ${ }^{12}$.

Rosa (2005), em sua pesquisa com pescadores artesanais da Área de Proteção Ambiental de Guapimirim (APA Guapimirim), na BG, certifica-se que no ano de 2000 havia cerca de 18 mil pescadores distribuídos entre as 5 colônias existentes na BG (ROSA, 2005: 46). Outras fontes consultadas pela autora afirmaram que este quantitativo era de 21.800 pescadores artesanais (ROSA, 2005: 46). Outros autores, como Vieira, Leal, Martins (2017), se certificaram que, somente na competência da colônia Z-9, em Magé, havia 1800 pescadores cadastrados, em 2017 (VIEIRA, LEAL, MARTINS, 2017:281).

No portal de transparência do Governo Federal é fornecido o quantitativo nominal, por município - e não por colônia -, dos pescadores artesanais que possuem RGP e recebem regularmente o seguro defeso ${ }^{13}$. Segundo este site, em Magé existiam 432 pescadores cadastrados no RGP, em 2020. Destes, 30\% são mulheres. O problema desses dados, ofertados pelo site, é que nem todos os pescadores e pescadoras, de Magé, possuem RGP, ou seja, não possuem sua atividade regulamentada pelas instituições que

\footnotetext{
${ }^{12}$ A não ser que consideremos, somente, os pescadores artesanais que recebem o seguro defeso, logo possuem RGP. Estes dados estão disponíveis no portal de transparência do governo federal, a partir de 2013, apenas: http://www.portaltransparencia.gov.br/beneficios/consulta?ordenarPor= mesAno\&direcao=desc.

${ }^{13}$ http://www.portaltransparencia.gov.br/beneficios/consulta?ordenarPor=mesAno\&direcao=desc.
} 
gerenciam a pesca, logo, não aparecem na lista existente no site. Devido a isto, o portal de transparência do governo federal, não é uma fonte que sirva para contabilizar o total de pescadores existentes em um município, muito menos por gênero. Portanto, para se realizar uma pesquisa com esse grupo de indivíduos, é necessário recorrer a métodos que facilitem a coleta de informações, em nível primário - relatos e dados computáveis -, como o trabalho de campo, conforme já apresentamos, anteriormente, neste artigo.

\section{Existe uma comunidade de pescadoras artesanais? Ou, existem pescadoras na comunidade de pescadores artesanais?}

Além da baixa oferta de informações secundárias sobre as pescadoras artesanais, a dificuldade de encontrá-las facilmente em seus ambientes de trabalho levantou a dúvida sobre a existência de uma comunidade. Para sanar esta questão, dialogamos com o sociólogo Max Weber, em partes do texto de seu livro Conceitos Sociológicos Fundamentais, onde ele afirma que o que define a comunidade é um "'sentimento' da situação comum e das suas consequências" (WEBER, 2010: 81).

A "comunidade" encontrada, em campo, caracteriza-se por vidas individualistas e fechadas em seus próprios lares, resolvendo questões no âmbito doméstico, dentre os familiares e não na vizinhança. O modo de vida da pesca artesanal é passado de pai para filhas e filhos e, esse modo de vida, é compartilhado dentre as pescadoras, mesmo que elas não se conheçam, afinal, os códigos de referência às técnicas e usos dos petrechos de pesca são os mesmos. Apesar de não termos encontrado uma "comunidade" aos moldes dos apresentados nas pesquisas sobre pesca artesanal, compreendemos que, não importam os desvios, a comunidade existe.

WEBER (2010) afirma que uma das constituições de comunidade se baseia em relações de "solidariedade sentida (afectiva ou tradicional) dos participantes" (WEBER, 2010: 77). Consideramos que, apesar de não termos presenciados casos de solidariedade entre as pescadoras entrevistadas, existem outros elementos que configuram a 
constituição de uma comunidade, como, por exemplo, a partir de um núcleo familiar. Ao encontrarmos essas mulheres, a maioria delas estava na intimidade de seus lares, envolvida nas atividades domésticas e nas relações familiares. Concordamos com WEBER (2010), quando ele afirma que, até mesmo, a família constitui uma comunidade:

A constituição da comunidade pode assentar em toda a espécie de fundamentos afectivos, emocionais ou tradicionais: uma confraria pneumática, uma relação erótica, uma relação de piedade, uma comunidade "nacional", uma tropa unida por sentimentos de camaradagem. A comunidade familiar é a que expressa de modo mais conveniente este tipo (WEBER, 2010: 79).

Concebemos que, as comunidades familiares, nas quais pertencem as entrevistadas, são "micro comunidades" que juntas compõem a "macro comunidade" das pescadoras artesanais de Magé. Esta "macro comunidade" está inserida em uma comunidade maior, a dos pescadores artesanais de Magé que, junto com outras comunidades de pescadores compõem a comunidade dos pescadores artesanais da Baía de Guanabara. Na lógica de WEBER (2010), não existe uma única forma de constituição de comunidade, que podem ser desde pequenos núcleos familiares até grandes comunidades judaicas, cujos componentes podem não se conhecer ou compartilhar solidariedade, mas são unidos pela linguagem, história e cultura.

No caso das pescadoras artesanais de Magé, contempladas nesta pesquisa, notamos que o que as une, e as faz pertencerem a uma comunidade, que "documenta uma copertença sentida" (WEBER, 2010: 81), são os (a) modos de vida, (b) as identidades construídas de si e para si mesmas e, por outro lado, (c) a dificuldade na construção da identidade para o "outro" (colônia de pescadores, por exemplo), (d) o compartilhamento dos mesmos problemas que as impactam e (e) o envolvimento nos mesmos projetos de ajuda aos pescadores - os oferecidos pelas ONGs e UCs, por exemplo. São realidades que as pescadoras artesanais enfrentam nas escalas local, regional e nacional. 
Identidade das pescadoras artesanais de Magé, de si, para si e para os "outros"

Dentre os desafios enfrentados pelas pescadoras artesanais de Magé, um dos maiores é provar sua existência e sua identidade, principalmente quando estas mulheres se deparam com a necessidade de terem seus direitos trabalhistas e previdenciários respeitados e reconhecidos. Apesar de se autoidentificarem pescadoras, suas identidades são vistas com desconfiança e desencorajamento e, devido a esta falta de credibilidade, as identidades estão constantemente ameaçadas pelas instituições que regulam a pesca, como a colônia de pescadores.

Nos apoiamos na reflexão do sociólogo Michel Pollak (1995) que afirma que "o sentimento de identidade (...) é o sentido da imagem de si, para si e para os outros" (POLLAK, 1995: 38). A partir desta afirmação, identificamos na vida das pescadoras artesanais de Magé três agentes que interferem na construção de suas identidades: (a) elas mesmas, com suas autoimagens e seus autorreconhecimentos, (b) os "outros" que promovem a descontinuidade da identidade, como a colônia de pescadores, por exemplo, e (c) os "outros" que são os promotores da identidade.

Sobre elas mesmas, a identidade se promove "de si e para si", conforme o argumento de POLLAK (1995). A partir dessa premissa, nos questionamos: o que as torna pescadoras artesanais? Sabemos que as práticas espaciais relacionadas à pesca, os seus modos de vida, como pescadoras, e as suas percepções ambientais sobre as condições da natureza que possibilitam a atividade pesqueira, são elementos fundamentais que constroem a identidade dessas pescadoras, de si e para si.

POLLAK (1995) afirma que na

construção da identidade (...) há três elementos essenciais (...) a unidade física [da pessoa ou do grupo] (...); a continuidade dentro do tempo, (...); [e] o sentimento de coerência (POLLAK, 1995: 38). 
Desse modo, a construção da identidade, de si e para si, depende da forma como a pescadora se vê, que, conforme POLLAK (1995), é "a imagem que uma pessoa adquire ao longo da vida referente a ela própria" (POLLAK, 1995: 38). A imagem que a pescadora tem de si mesma está relacionada ao seu corpo, que é a "unidade física" do seu primeiro instrumento de trabalho, à continuidade de sua imagem construída desde a infância, quando aprendeu o ofício, e ao sentimento de coerência, que é a coesão entre o corpo (unidade física) e a continuidade, refletidas nas práticas espaciais e nos modos de vida dessas mulheres.

Foi através das entrevistas, onde as pescadoras relataram suas questões relacionadas à pesca, que elas expuseram e reconstruíram suas imagens que possuem de si, reafirmando suas identidades de pescadoras. Conforme POLLAK (1995), é pelas entrevistas que o indivíduo expõe o "sentimento de continuidade e da coerência (...) em sua reconstrução de si" (POLLAK, 1995: 38), quando lembram da sua própria história de vida. A construção da identidade de si e para si é a primeira forma de entendimento da própria imagem do indivíduo, como no caso das pescadoras. Esse entendimento garante a unidade, a continuidade e a coerência de suas identidades, afastando qualquer possibilidade de desconstrução desta primeira configuração da identidade, de si e para si. Porém, a construção da identidade integral também leva em consideração o elemento "outro". De acordo com POLLAK (1995), a "auto-imagem [não é uma construção] isenta de mudanças, de negociação, de transformação em função dos outros" (POLLAK, 1995: 38).

Em relação aos "outros", os que promovem a descontinuidade da identidade, no caso das pescadoras artesanais de Magé, identificamos a colônia de pescadores local e os órgãos governamentais que regulam o cadastro dos pescadores (Ministérios, secretarias e o INSS). As pescadoras artesanais dependem desses agentes para o cadastro do RGP e o recebimento dos benefícios trabalhistas e previdenciários.

Para que essas mulheres estejam de acordo com os critérios estabelecidos por esses agentes e serem reconhecidas como pescadoras, de fato, faz-se necessário que suas identidades sejam coesas na unidade, na continuidade e na coerência. No entanto, a 
insegurança na identidade dessas pescadoras, provocada pelo desencorajamento ao cadastro no RGP, pela colônia, e a ausência de apoio e de fortalecimento da atividade pesqueira, principalmente a praticada por mulheres, fazem com que haja uma ruptura no sentimento de identidade: "se houver forte ruptura no sentimento de unidade ou de continuidade, podemos observar fenômenos patológicos" (POLLAK, 1995: 38) na construção da identidade.

A identidade vai além da autoidentificação e autorreconhecimento; ela passa pelo crivo público, como compreendido por POLLAK (1995) que afirma que

a memória e a identidade são valores disputados em conflitos sociais e intergrupais, e particularmente em conflitos que opõem grupos políticos diversos (POLLAK, 1995: 38-39).

Em nossa pesquisa, a afirmativa de POLLAK (1995) serve para compreendermos que, a forma como as pescadoras são tratadas pelos agentes que frequentam seus espaços depende da relação entre ambos os lados: o das pescadoras e o das instituições que regulamentam a pesca, como a colônia de pescadores. Esta relação se constrói, também, pela forma como este "outro" vê as pescadoras, ou seja, a imagem destas trabalhadoras para a colônia e demais instituições é o que configura a identidade para os "outros". E essa relação viola a autoidentidade, a autoimagem e o autorreconhecimento, de si e para si, que essas mulheres constroem ao longo de suas vidas.

Apesar da relação destrutiva entre as pescadoras e os "outros", que promovem a descontinuidade e a insegurança identitária, existem aqueles "outros" definidos nesta pesquisa como os promotores da identidade. Falaremos brevemente sobre estes últimos agentes, para finalizar a discussão sobre o nosso diálogo com POLLAK (1995). Estes agentes que promovem a identidade e seu fortalecimento, não foram contemplados na seção em que apresentamos alguns resultados (porcentagens e relatos), mas pincelaremos neste último parágrafo, para completar o raciocínio. 
Os problemas que atropelam as vidas das pescadoras artesanais que colaboraram com esta pesquisa não ocorrem com exclusividade em Magé. As questões relacionadas às zonas de sacrifício, perda de benefícios trabalhistas e previdenciários e o desencorajamento das pescadoras, pelas colônias, ocorrem em nível nacional. Para o enfrentamento aos obstáculos impostos, surgiram organizações que representam os pescadores artesanais como o Movimento de Pescadores e Pescadoras Artesanais (MPP), a Articulação Nacional das Pescadoras (ANP), o Conselho Pastoral dos Pescadores (CPP), entre outras.

Essas organizações podem ter surgido como efeito aos impactos sofridos pelos pescadores e pescadoras de nosso país, cujo surgimento pode ser entendido como parte de um "trabalho de enquadramento de memória" (POLLAK, 1995: 40). Para POLLAK (1995), as memórias individuais e coletivas são importantes na construção da identidade (POLLAK, 1995: 40), sendo este o papel dos agentes que promovem a identidade. A partir do momento em que as pescadoras e pescadores artesanais precisam que suas identidades, de si e para si, sejam respeitadas pelos "outros", essa construção passa a ser política. Por isso a importância da criação de uma memória de grupo, que possa ser lembrada, reconhecida e enquadrada na história de luta da categoria.

\section{Conclusões}

A invisibilidade da pescadora artesanal não repousa apenas na injusta divisão do trabalho familiar e na "tripla" jornada de trabalho que a mulher assume, fatores identificados na literatura e no trabalho de campo. A invisibilidade está, também, na falha do reconhecimento institucional, ou seja, as pescadoras não são reconhecidas como tais pelas próprias instituições ligadas à pesca, como a colônia de pescadores. Mesmo assim, enquanto pescadora, a identidade, de si e para si (POLLAK, 1995), se preserva no seu conhecimento das práticas espaciais relativas à pesca artesanal, na sua memória da infância e adolescência, quando aprenderam a pescar com seus familiares, 
no tempo de experiência e permanência neste trabalho e na sua participação nas etapas do beneficiamento.

Uma das dificuldades encontradas durante o trabalho de campo foi a de encontrar as pescadoras artesanais, de modo que precisei recriar estratégias de pesquisa. Essa dificuldade me fez duvidar se haveria uma comunidade de pescadoras ou se haveriam pescadoras na comunidade. Uma das conclusões a que chegamos é que apesar de não termos presenciado relações de vizinhança e solidariedade, conforme nos apontou WEBER (2010), dentre as pescadoras artesanais, o que as une são as práticas espaciais de pesca, o modo de vida, como pescadoras, as dificuldades encontradas para terem suas identidades reconhecidas, as questões com os benefícios trabalhistas e previdenciários, dentre outros, comuns à comunidade de pescadores, em geral.

A vida das pescadoras artesanais entrevistadas é muito ocupada, de modo que sempre precisei marcar os encontros em suas casas, onde, frequentemente, estavam envolvidas com as responsabilidades domésticas, que precisariam ser organizadas a tempo de se dedicar às demais atividades, como a pesca. O acúmulo de atividades triplica suas jornadas de trabalho, mas, por sua vez, auxiliam na economia familiar, principalmente, quando a época não está boa para captura - depende da estação do ano, das marés, das condições climáticas, dos petrechos estarem em bom estado etc.

Quase $40 \%$ das mulheres entrevistadas foram desencorajadas pela colônia de pescadores a se registrarem profissionalmente como pescadora artesanal (CHAVES, 2021). Apesar da amostragem ter sido de 19 pescadoras, e não conhecermos o quantitativo de pescadoras existentes na região, por falta de um censo, os motivos dados a estas pescadoras foram preocupantes. As pescadoras apresentadas como exemplo neste artigo, todas elas possuem mais de 30 anos de pesca e, por terem procurado a colônia tardiamente, os funcionários que as atenderam lhes disseram que "não valia mais a pena". Para conseguirem se aposentar, por exemplo, as pescadoras deveriam ter 15 anos de contribuição ao INSS, até os 55 anos de idade (SILVA, 2015). Isto leva a duas conclusões, que serão expostas nos parágrafos seguintes. 
A primeira conclusão é que, apesar das pescadoras reconhecerem-se a si mesmas como pescadoras artesanais, trabalharem com isso e sobreviverem disso, a identidade delas, para os "outros", não é coesa o suficiente (POLLAK, 2010), provavelmente pela ausência de políticas públicas que fortaleçam a categoria, por gênero. Mesmo que agentes de auxílio aos pescadores estejam presentes no território pesqueiro, como as ONGs e as UCs, suas ajudas são externas e as afastam da pesca, não as aproxima. Isto é, oferta-se novas oportunidades de trabalhos remunerados, desconectados da pesca. O que fortalece a identidade da pesca são agentes internos, criados pelos próprios pescadores, como as associações de pescadores locais e os movimentos nacionais, como o MPP, a ANP e o CPP.

A segunda conclusão é que, apesar da colônia ser compreendida, nacionalmente, como o principal órgão local de regulamentação da pesca (DUARTE, 1999, SILVA, 2015), não existe uma preocupação desta entidade em fortalecer a atividade pesqueira na zona que ela abarca (o Z da colônia vem de "zona"). Pelo menos, aparentemente, não presenciamos ações de proteção às mulheres que são pescadoras artesanais, mesmo que a presidenta da colônia de pescadores local seja uma mulher ${ }^{14}$. Esta falta de assistência proativa fica evidente quando pescadoras não sabem como registrar o RGP ou contribuir com o INSS, por exemplo ( $47 \%$ das pescadoras entrevistadas não fazem esta contribuição).

As políticas públicas para a pesca, tanto para os homens quanto para as mulheres, deveriam ser mais bem divulgadas e aplicadas de forma justa. A falta de transparência dos órgãos que regulam a pesca faz com que a maioria das pescadoras procurem somente a colônia, por não saberem que podem ir diretamente às autarquias do governo - MAPA, SAP e INSS. A colônia, de certo modo, é usada como despachante por estes e estas profissionais e não os informa sobre o que deve ser feito, tornando-os reféns de seus serviços - e, também, ampliando sua lista de contribuintes. Isso se torna

\footnotetext{
${ }^{14}$ http://mage.rj.gov.br/oleo-em-mage-entidades-se-reuniram-para-tracar-as-proximas-acoes/.
} 
um nó nesta rede de instituições e, no caso das pescadoras artesanais, torna-se um entrave na regularização profissional dessas mulheres.

\section{Referências bibliográficas}

ALERJ (2016). 5.1. Dossiê do presidente da Comissão Especial. In: Relatório da Comissão Especial da Baía de Guanabara. Autores do Dossiê: Carla Ramôa Chaves, Carlos Bittencourt e Flávio Serafini. pp. 1 [65] - 215 [281]. Disponível em: <https://drive.google.com/file/d/OBzH9dHAzOI6IZ201Z25jY216cUFxc1IEX1UtWU hGbHVMdWFV/view>. Acesso em: 13/06/2020.

BERREMAN, Gerard D. (1962) "Etnografia e controle de impressões em uma aldeia do Himalaia". In: GUIMARÃES, Alba Zaluar, org. Desvendando Máscaras Sociais. Rio de Janeiro: Livraria Francisco Alves Editora S.A., p.123-174.

BERQUE, A. (1984). Paisagem-marca, paisagem-matriz: elementos da problemática para uma Geografia Cultural. In: In: CORRÊA, R.L. ; ROSENDAHL, Z. Paisagem, tempo e cultura. Rio de Janeiro: EdUERJ, 1998. pp. 84-91.

BRASIL (2015). Decreto no 8.424 de 31 de março de 2015. Regulamenta a Lei no 10.779, de 25 de novembro de 2003, para dispor sobre a concessão do benefício de segurodesemprego, durante o período de defeso, ao pescador profissional artesanal que exerce sua atividade exclusiva e ininterruptamente. Disponível em: <http://www.planalto.gov.br/ccivil_03/_ato2015-

2018/2015/decreto/d8424.htm>, acessado em 12/01/2021.

CHAVES, C.R. (2011). Mapeamento Participativo da Pesca Artesanal da Baía de Guanabara. Dissertação de Mestrado - Universidade Federal do Rio de Janeiro: Programa de Pós-Graduação em Geografia. 185p.

(2021). Nos manguezais e no "mar" de Magé: um estudo sobre pescadoras artesanais e suas existências, resistências e identidades. Tese de Doutorado Universidade Federal do Rio de Janeiro: Programa de Pós-Graduação em Geografia. 284p.

CLAVAL, P. (1999). Etnogeografias: conclusão. In: Espaço e Cultura, UERJ, RJ, n. 7, Jan/Jun. de 1999. pp. 69-74. Disponível em: <https://www.epublicacoes.uerj.br/index.php/espacoecultura/article/view/6995>. Acesso em:18/05/2020. 
(2002). A contribuição francesa ao desenvolvimento da abordagem cultural na Geografia. In: CORRÊA, R.L.; ROSENDAHL, Z. Introdução à geografia cultural. 2응 ed. Rio de Janeiro: Bertrand Brasil, 2007. pp.147-166.

(2013). O papel do trabalho de campo na geografia, das epistemologias da curiosidade às do desejo. In: Confins [En ligne], 17 | 2013, mis en ligne le 22 octobre 2017. Disponível em:<http://journals.openedition.org/confins/12414>. Acesso em:18/05/2020.

COELHO, B. H. da S. (2017). Potencialidades e limites de conselhos de unidades de conservação: considerações sobre a implantação do Comperj na região do Mosaico Central Fluminense. Tese de Doutorado: Universidade Federal do Rio de Janeiro, Programa e Pós-Graduação em Psicossociologia de Comunidades e Ecologia Social, $295 p$.

COLE, Sally (1991). Women of the praia: work and lives in a Portuguese coastal Community. In the United Kingdom: Princeton University Press, Oxford. 189p.

COSTA, A. L. M. (2013). Uma retirada insólita: Rio São Francisco - barragem de Sobradinho. Rio de Janeiro: Universidade Federal do Rio de Janeiro/IPPUR. 272p.

DI CIOMMO, Regina Celia (2007). Pescadoras e pescadores: a questão da equidade degênero em uma reserva extrativista marinha. In: Ambiente \& Sociedade. Campinas, v. X, n. 1, p. 151 - 163, jan-jun/ 2007. Disponível em: <http://www.scielo.br/pdf/asoc/v10n1/v10n1a10>. Acesso em: 24/06/2019.

DUARTE, L.F.D. (1999). As redes do suor: a reprodução social dos trabalhadores da pesca em Jurujuba. Niterói: EdUFF, 1999. 285p.

FASSARELA, Simone Simões (2008). O trabalho feminino no contexto da pesca artesanal: percepções a partir do olhar feminino. In: SER Social, Brasília, v. 10, n. 23, p. 171 194, jul/ dez, 2008. Disponível em: <http://periodicos.unb.br/index.php/SER_Social/article/view/12956>.Acesso em: 24/06/2019.

FERREIRA, M. A. G. (2016). Entre redes de discursos e de pesca: performances narrativas de mulheres pescadoras em Arraial do Cabo. Tese de Doutorado, UFRJ: Programa de Pós-Graduação em Linguística aplicada. 199p.

FOOTE-WHYTE, William. (1943). Treinando a observação participantes. In: ZALUAR, Alba. (org.) Desvendando máscaras sociais. Rio de Janeiro: Francisco Alves, 1980. 77-86pp.

GEERTZ, C. (2008). Um jogo absorvente: Notas sobre a Briga de Galo Balinesa. In: A interpretação das culturas. Rio de Janeiro: LCT. pp. 278-320. 
GERBER, Rose Mary (2013). Mulheres e o mar: uma etnografia sobre pescadoras embarcadas na pesca artesanal no litoral de Santa Catarina, Brasil. Tese (Doutorado) - Programa de Pós-graduação em Antropologia Social da Universidade Federal de Santa Catarina (PPGAS - UFSC), 2013, 418 pp. Disponível em:<https://repositorio.ufsc.br/bitstream/handle/123456789/107184/319165.p df? sequence=1\&isAllowed=y>. Acesso em: 22/06/2019.

GLUCKMAN, M. (1958). Análise de uma situação social na Zululândia moderna. In: FELDMAN-BIANCO, Bela (org.). Antropologia das sociedades contemporâneas. Métodos. São Paulo: Editor UNESP, 2009. pp. 227-267.

HOEFLE, S. W. (2018). A Ecologia Política da Costa Fluminense: um estudo etnográfico longitudinal da pesca, turismo e desenvolvimento industrial na Baía de Sepetiba. In: Revista Brasileira de Geografia. Rio de Janeiro, v. 63, n. 1, p. 99-128. Disponível em: <https://rbg.ibge.gov.br/index.php/rbg/article/view/192>, Acesso em: 15/10/2019.

LAMÊGO FILHO, A. R. (1964). III - O homem e a Guanabara. Edição comemorativa do IV centenário da cidade do Rio de Janeiro, 2a edição, Instituto Brasileiro de Geografia e Estatística, Conselho Nacional de Geografia, 415p. Disponível em: <https://biblioteca.ibge.gov.br/visualizacao/livros/liv13101_v3.pdf>, acessado em 03/02/2020.

MALINOWSKI, Bronislaw. (1961). Os Argonautas do Pacífico Ocidental (Introdução: objeto, método e alcance desta investigação). In: Ethnologia, Revista do Departamento de Antropologia da Faculdade de Ciências Sociais e Humanas: Universidade de Lisboa. n.s. 6-8: 17-38. [o autor realizou esta pesquisa entre os anos de 1914 até 1918, mas este texto foi republicado por esta revista em 1997. Não se trata da pesquisa inteira.]

MANESCHY, M. C. (1995) A mulher está se afastando da pesca? Continuidade e mudança no papel da mulher na manutenção doméstica entre famílias de pescadores no litoral do Pará. In: Boletim do Museu Paranaense Emílio Goeldi, série Antropológica, v. 11, n.2. Disponível em: <http://repositorio.museugoeldi.br/bitstream/mgoeldi/821/1/B\%20MPEG\%20Ant\%2011(2)\%201995\%20M ANESCHY.pdf>. Acesso em: 17/04/2018.

MAPA (2019). Relatório de avaliação: Secretaria Especial de Previdência e Trabalho do Ministério da Economia. Brasília: Ministério da Agricultura, Pecuária e Abastecimento (MAPA). maio, 2019. 17p. Disponível em: <https://auditoria.cgu.gov.br/download/12934.pdf>, acesso 03/03/2020. 
MARTINS, Maria Cristina. (2005). Partilhando saberes na Ilha de Itaóca: a roda de siri entre o mundo do trabalho e as memórias da infância. Tese de Doutorado em Educação: Universidade Federal Fluminense. 263p. Disponível em: $<$ http://docplayer.com.br/34546977-Partilhando-saberes-na-ilha-de-itaoca-aroda-de-siri-entre-o-mundo-do-trabalho-e-as-memorias-de-infancia.html>. Acesso em: 21/05/2020.

- (2008). Práticas de trabalho e produção de saberes no cotidiano de mulheres pescadoras. In: Sisifo: revista de ciências da educação. № 6. maio/agosto de 2008. pp. 71-84. Disponível em: <sisifo.ie.ulisboa.pt/index.php/sisifo/article/download/194/346>. Acesso em: 23/06/2019.

POLLAK, M. (2006). Memoria e Identidad Social. In: Memoria, olvido, silencio: la producción social de identidades frente a situaciones limite. La Plata: Ediciones Al Margen. 117p. (pp. $33-52$ ).

RAULINO, S. F. (2013). Riscos, empregos, "desenvolvimento" e condições de vida: temor e consentimento nas representações de populações que sofrem efeitos de proximidade da REDUC. In: Fórum dos atingidos pela indústria do petróleo e petroquímica nas cercanias da Baía de Guanabara (org.). 50 anos da Refinaria de Duque de Caxias e a expansão da indústria petrolífera no Brasil: conflitos socioambientais no Rio de Janeiro e desafios para o país na era do Pré-Sal. Heinrich Böll Stiftung, Fase - solidariedade e educação, 1a edição, Rio de Janeiro, 2013. pp. 169-199.

SEEGER, A. (1980). Pesquisa de campo: uma criança no mundo. In: SEEGER, A. Os índios e nós. Rio de Janeiro: Campus, 1980. pp. 25-40.

SILVA, Cátia Antônia da (2015). Política Pública e território: passado e presente da efetivação de direitos dos pescadores artesanais no Brasil. Rio de Janeiro: Consequência. 130p.

SOARES, Sara M. (2012). Descaindo a rede do conhecimento: as pescadoras e o seguro defeso na comunidade Cristo Rei no Careiro da Várzea. Dissertação (Mestrado) Programa de Pós-Graduação em Sociedade e Cultura na Amazônia (PPGSCA), Universidade Federal do Amazonas, 2012, pp. 145. Disponível em: <https://tede.ufam.edu.br/handle/tede/2311>.Acesso em: 25/06/2019.

VEIGA, L.; GONDIM, S. M. G. (2001). A utilização de métodos qualitativos na Ciência Política e no Marketing Político. In: Opinião Pública. Campinas, vol. VII, nำ1, 2001, pp. 1-15. Disponível em: <https://www.scielo.br/pdf/op/v7n1/16930.pdf>. Acesso em: 21/05/2020. 
VIEIRA, Thiago W. M.; LEAL, G. F.; MARTINS, R. L. (2017). Novo desenvolvimentismo e conflitos ambientais na Baía de Guanabara: o Complexo Petroquímico do estado do Rio de Janeiro (COMPERJ) e os pescadores artesanais. In: Revista Desenvolvimento e Meio Ambiente. Universidade Federal do Paraná, v. 42, p. 271286, dezembro $2017 . \quad$ Disponível em: <https://revistas.ufpr.br/made/article/view/46934/34455>. Acesso em: $17 / 11 / 2020$.

WEBER, M. (2010). Conceitos Sociológicos Fundamentais. Covilhã: LusoSofia Press. 110p. Disponível em: <https://b-ok.lat/book/1061667/0e90e7> Acesso em: 20/12/2020.

WEISS, Robert S. (1994). Learning from stranger: the art and method of qualitative interview studies. New York, The Free Press. Disponivel em: <https://books.google.com.br/books?id=i2RzQbiEiD4C\&pg=PA15\&hl=pt-

$B R \&$ source=gbs_toc_r\&cad=4\#v=onepage \&q\&f=false>. Acesso em 03/02/2021.

Data de Submissão: 31/03/2021

Data do Aceite: 26/04/2021 